\title{
VOICES OF
}

\author{
MENTAL HEALTH
}




\section{Other books by Martin Halliwell}

Romantic Science and the Experience of Self (1999; 2016)

Modernism and Morality (200I)

republished as Transatlantic Modernism (2006)

Critical Humanisms: Humanist/Anti-Humanist Dialogues (2003)

(with Andy Mousley)

Images of Idiocy: The Idiot Figure in Modern Fiction and Film (2004)

The Constant Dialogue: Reinhold Niebuhr and

American Intellectual Culture (2005)

American Culture in the 1950s (2007)

American Thought and Culture in the 21st Century (2008)

(edited with Catherine Morley)

Beyond and Before: Progressive Rock since the 1960s (20II)

(with Paul Hegarty)

Therapeutic Revolutions: Medicine, Psychiatry, and

American Culture, 1945-1970 (2013)

William James and the Transatlantic Conversation (2014)

(edited with Joel Rasmussen)

Neil Young: American Traveller (2015)

Reframing 1968: American Politics, Protest and Identity (forthcoming)

(edited with Nick Witham) 


\section{VOICES OF MENTAL HEALTH}

Medicine, Politics, and

American Culture, 1970-2000

MARTIN HALLIWELL

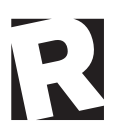

RUTGERS UNIVERSITY PRESS

New Brunswick, Camden, and Newark, New Jersey, and London 


\section{Library of Congress Cataloging-in-Publication Data}

Names: Halliwell, Martin, author.

Title: Voices of mental health : medicine, politics, and American culture, 1970-2000 / Martin Halliwell.

Description: New Brunswick, New Jersey : Rutgers University Press, [2017] | Includes bibliographical references and index.

Identifiers: LCCN 2016053289| ISBN 9780813576787 (hardcover : alk. paper) | ISBN 97808I3576794 (e-book (epub)) | ISBN 9780813576800 (e-book (web pdf))

Subjects: | MESH: Mental Disorders-history | Mental Disorders-therapy | Health Policy-history | Mental Health Services-economics | Psychiatry in

Literature | Motion Pictures as Topic | History, 2oth Century | United States

Classification: LCC RC455 | NLM WM ir AAI | DDC 362.196/89-dc23

LC record available at https://lccn.loc.gov/2016053289

A British Cataloging-in-Publication record for this book is available from the British Library.

Copyright (C) 2017 by Martin Halliwell

All rights reserved

No part of this book may be reproduced or utilized in any form or by any means, electronic or mechanical, or by any information storage and retrieval system, without written permission from the publisher. Please contact Rutgers University Press, ro6 Somerset Street, New Brunswick, NJ 0890I. The only exception to this prohibition is "fair use" as defined by U.S. copyright law.

(0) The paper used in this publication meets the requirements of the American National Standard for Information Sciences-Permanence of Paper for Printed Library Materials, ANSI Z39.48-1992.

www.rutgersuniversitypress.org

Manufactured in the United States of America 